\title{
The oldest aphid of the family Oviparosiphidae (Hemiptera: Aphidoidea) from the Middle Jurassic of China
}

\author{
Diying HUANG ${ }^{1}$, Piotr WEGIEREK ${ }^{2}$, Dagmara ŻYŁA ${ }^{3, *}$ and André NEL ${ }^{4}$ \\ ${ }^{1}$ State Key Laboratory of Palaeobiology and Stratigraphy, Nanjing Institute of Geology and Palaeontology, Chinese Academy \\ of Sciences, Nanjing 210008, P.R. China; e-mail: huangdiying@sina.com \\ ${ }^{2}$ Department of Zoology, University of Silesia, Bankowa 9, 40-0007 Katowice, Poland; e-mail: piotr.wegierek@us.edu.pl \\ ${ }^{3}$ Polna 4, 42-672 Wieszowa, Poland; e-mail: zyladagmara@gmail.com \\ ${ }^{4}$ CNRS UMR 5202, CP 50, Entomologie, Muséum National d'Histoire Naturelle, 45 Rue Buffon, F-75005, Paris, France; \\ e-mail: anel@mnhn.fr
}

Key words. Hemiptera, Aphidoidea, Oviparosiphidae, aphids, fossil, Middle Jurassic, Daohugou, China, new genus and species

\begin{abstract}
We describe herein a new aphid genus and species Daoaphis magnalata gen. et sp. n., belonging to the extinct family Oviparosiphidae from the Middle Jurassic (ca. $165 \mathrm{Ma}$ ) Daohugou beds, Ningcheng County, Inner Mongolia, Northeast China. The new genus is considered to be the earliest certain representative of this family and the body remains of one of the oldest aphids. The evolutionary position of this new genus and distribution of the family are discussed.
\end{abstract}

\section{INTRODUCTION}

The oldest aphids are known from the Triassic. The first, Triassoaphis cubitus Evans, 1956, was recorded in the Carnian of Australia and assigned to the family Triassoaphididae. The second, Creaphis theodora Shcherbakov \& Wegierek, 1991 was described from the Ladinian-Carnian of Kyrgyzstan and placed in the family Creaphididae (Heie \& Wegierek, 2011). Shcherbakov (2010) describes the oldest aphid wing from the Anisian of the Vosges, Leaphis prima and assigned it to the subfamily Leaphidinae in the Creaphididae. Most Triassic aphids are known from isolated wings, except the Dracaphididae of the superfamily Naibioidea described from the Middle Triassic of China (Hong et al., 2009). Jurassic aphids are also scarce and only seven species are described. They belong to five families: Genaphididae, Juraphididae, Oviparosiphidae, Sinojuraphididae and Szelegiewicziidae; there is also one species unassigned to any high taxonomic rank (Heie \& Wegierek, 2011; Żyła et al., 2014).

The oldest representative of the extinct family Oviparosiphidae is Grimmenaphis magnifica Ansorge, 1996, described from the Upper Liassic (Lower Jurassic) deposit of Grimmen, (Germany), but it is known only from an isolated wing (Ansorge, 1996). The oldest undoubted species is Khotontaphis lachnoides Shaposhnikov \& Wegierek, 1989 from the Upper Jurassic/Lower Cretaceous deposit at Khotont (Mongolia). More Oviparosiphidae are known from the Early Cretaceous but they are absent from the Upper Cretaceous sediments (Heie \& Wegierek, 2011). This family is very diverse morphologically, but all taxa have both an ovipositor and siphons on the abdomen (Shaposhnikov, 1979). Such a combination is not present in any recent aphids, which never have both of those structures (Heie, 1981).

The deposit at Daohugou (Ningcheng County, Inner Mongolia of China) has yielded a very rich array of vertebrate, invertebrate and plant fossils (e.g. Huang et al., 2006; Pott et al., 2012; Sullivan et al., 2014). More than 20 different insect orders are described, including very diverse hemipterous groups (Huang, 2014). Aphids are very rare in the Daohugou biota and only a monotypic aphid family, the Sinojuraphididae, is described from this locality (Huang \& Nel, 2008).

The present paper describes a new genus and a new species belonging to the family Oviparosiphidae from the Daohugou beds. This is the oldest representative of the family, which allows for the analysis of both the wing and body with its appendages. The single specimen was collected from the Xiayingzi locality of Daohugou beds at the Daohugou Village, Ningcheng County, Inner Mongolia. This fossil layer yielded very rich invertebrate fossils such as giant fleas, peculiar Diptera namely Strashila, and the earliest Mantophasmatodea (Huang et al., 2008, 2012, 2013).

\section{MATERIAL AND METHODS}

The material came from the Daohugou beds at the Xiayiingzi Quarry of the Daohugou Village, Shantou Township, Ningcheng County, Inner Mongolia, China $\left(41^{\circ} 18^{\prime} \mathrm{N}, 119^{\circ} 13^{\prime} \mathrm{E}\right)$. The specimen is housed in the Nanjing Institute of Geology and Palaeontology (NIGP), Nanjing, China. The fossil was prepared using a sharp knife. The aphid imprint is preserved in the form of two imprints, "reverse" (part) and "obverse" (counterpart). Because of the type of rock and parts of the chitinous skeleton are preserved it was possible to soak the fossil in $70 \%$ ethyl alcohol, which

\footnotetext{
* Corresponding author.
} 
facilitated our understanding of the morphology of selected parts of the body. The material was analyzed using typical methods of paleoentomological research (Rasnitsyn, 2002). Photographs were taken using a Zeiss Discovery V20 microscope system, with specimens moistened with alcohol or dry. All measurements are given in $\mathrm{mm}$.

The deposit is located within the Middle Jurassic-Early Cretaceous Ningcheng Basin, which is exposed along the boundaries of the provinces of Inner Mongolia, Hebei and Liaoning. The Daohugou beds constitute a succession of grey-white or locally brownish, finely laminated claystones, shales, siltstones and sandy mudstones, with intercalated ash-fall tuffs and ignimbrites (Pott et al., 2012). A distinctive feature of the Daohugou rock matrix is its laden with relatively small Euestheria conchostracans, but these are absent in the present layers which contain abundant anostracans instead (Huang et al., 2013). The geological age of the Daohugou beds indicated as ca. $165 \mathrm{Ma}$ at the late Middle Jurassic (Chen et al., 2004; Liu et al., 2004). The specimen is compressed in grayish shale and both part and counterpart are present. This insect was split through the gap between wings plus thorax sclerites. Thus, the photography indicates inner view of the body features. Therefore, some structures such as rostrum is underneath and not clearly visible.

\section{SYSTEMATIC PALAEONTOLOGY}

\section{Order Hemiptera Linnaeus, 1758}

Suborder Sternorrhyncha Amyot \& Serville, 1843

Infraorder Aphidomorpha Becker-Migdisova \& Aizenberg, 1962

\section{Superfamily Aphidoidea Latreille, 1802}

\section{Family Oviparosiphidae Shaposhnikov, 1979}

\section{Genus Daoaphis gen. n.}

Type species. Daoaphis magnalata sp. n.; by present designation and monotypy.

Etymology. Derived from the name of the deposit (Daohugou) and the Latin aphis, aphid.

Gender. Feminine.

Diagnosis. The body is large, thick and dorso-ventrally flattened anterior margin of head convex and epicranial suture present on head. Antennae with seven segments, long and bead-like, reaching the anterior part of the abdomen. Secondary rhinaria ellipsoidal, arranged in numerous transverse rows. The rostrum relatively long, but shorter than the length of the body, reaching to the base of hind coxae. Fore wings much longer than the body. Bases of veins $\mathrm{CuA}_{1}$ and $\mathrm{CuA}_{2}$ close to each other, but $\mathrm{CuA}_{2}$ not connected with the main vein $\mathrm{Sc}+\mathrm{R}+\mathrm{M}$. Hind wings extend beyond the apical part of the abdomen. Siphons porous.

\section{Species Daoaphis magnalata sp. n. (Figs 1, 2)}

Etymology. From the Latin magnus, big and ala, wing.

Holotype. NIGP 140801 (alate female).

Type locality. Xiayingzi Quarry at the Daohugou Village, Inner Mongolia, China.

Stratigraphic horizon. Late Middle Jurassic.

Diagnosis. As for the genus.

Description. Body unusually large (4.20); distance from anterior part of the head to the apex of the fore wing: 5.80. Width of the head, measured including eyes $(0.68)$, equal to half of its length (0.34). Width of the head between the eyes: 0.40 . Antennae equal to half of the body length. Segment III of antennae (0.69) $5 \times$ as long as it is wide, nearly equal to half of the cumulative length of subsequent segments. Segment IV (0.23) $2 \times$ longer than it is wide, one-third of the length of segment III. Segment V (0.36) $3.5 \times$ longer than it is wide, $1.5 \times$ longer than segment IV. Segment VI (0.52) almost $1.5 \times$ longer than segment V. Segment VII (0.12) shorter and narrower than the other segments, $2.5 \times$ narrower than segment III. The apical part of the rostrum between middle and hind coxae. Segment III of the rostrum short (0.08), nearly equal to the length of segment IV (0.10). Segment IV of the rostrum bluntended. The pronotum wider than the head, $3 \times$ wider $(0.90)$ than it is long. Anterior margin of the pronotum, without a clear line/border, merging with arcuate sides. The praescutum very small, 0.10 long, 0.20 wide. Metascuta wide apart, with a poorly sclerotized area between them. The mesopostnotum forms a short U-shaped slat, widely overlapping the sides of the body. Anterior part of the mesoscutellum forms a narrow strip with mesoscutellar arms extending well over the lateral part of the body. Length of the mesoscutellar arms equal to the width of the basal part of the mesoscutellum. Legs short. Distance between middle coxae (0.34) and hind coxae (0.39) no longer than their length. Hind coxae very close to each other, the distance between them shorter than their width (0.28). Fore tibiae (1.13) nearly one-fourth of the body length. Length of segment II of the fore tarsus: 0.37 . Length of the middle femur: 0.98; middle tibia: 1.21 ; segment II of the middle tarsus: 0.38 . Length of the hind femur: 1.16. Hind tibiae (1.49) one-third of the body length. Length of segment II of the hind tarsus: 0.44 . Fore wings (4.90) elongated and slender, longer than the body, probably flat in repose judging by the weakly developed praescutum. Width of the fore wing: 1.80-1.92. Apical part well-developed. Cubital veins slightly thickened. Apical part of vein $\mathrm{CuA}_{2}$ slightly curved towards the pterostigma, distal part slightly curved towards the base of the fore wing. Vein $\mathrm{CuA}_{1}$ arcuate, the apical part slightly sclerotized, the connection with the main vein not visible. Base of vein $\mathrm{M}$ directed towards the pterostigma, not connected with the main vein. Branches of vein $\mathrm{M}$ form a wide fork. The common stem of vein $\mathrm{M}$ nearly equal to the length of the stem of $\mathrm{M}_{1+2}$. The base of vein Rs, branching off vein $\mathrm{M}$ and apical part of $\mathrm{CuA}_{1}$ at the same level, at mid-length of the wing. Vein Rs slightly curved, leaving in the middle of the pterostigma. The pterostigma long and lenticular, $3 \times$ longer than wide. Hind wings (3.10) longer than half of the body length, with two cubital veins. Distance between the bases of cubital veins equal to half of the length of vein $\mathrm{CuA}_{2}$. The abdomen slightly sclerotized. Diameter of siphons: 0.12 .

\section{DISCUSSION}

The oldest species assigned to the Oviparosiphidae, Grimmenaphis magnifica, was assigned to this family on the basis of two features: three-branched vein $M$ and bases of cubital veins arising from one point on the main vein 

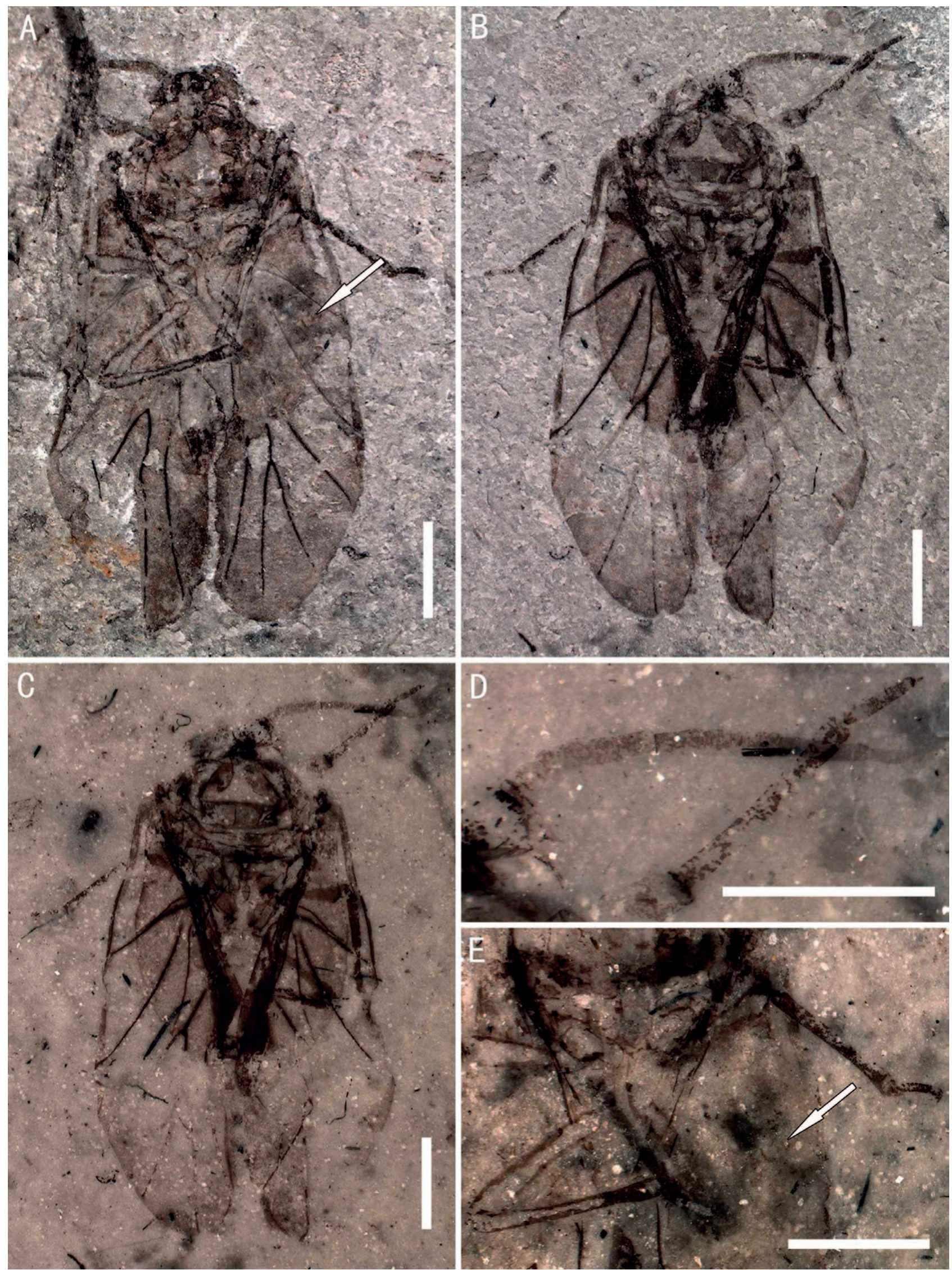

Fig. 1. Daoaphis magnalata gen. et sp. n. from the Middle Jurassic Daohugou beds, Ningcheng County, Inner Mongolia, Northeast China (holotype). A - the part (NIGP 140801a) showing the general habitus, dorsal view (dry); B - the counterpart (NIGP140801b), showing the general habitus, ventral view (dry); C - the counterpart, ventral view (moistened with $70 \%$ alcohol); D - left antenna; E part of abdomen with siphons (arrow indicates the siphons). Scale bars: $1 \mathrm{~mm}$. 


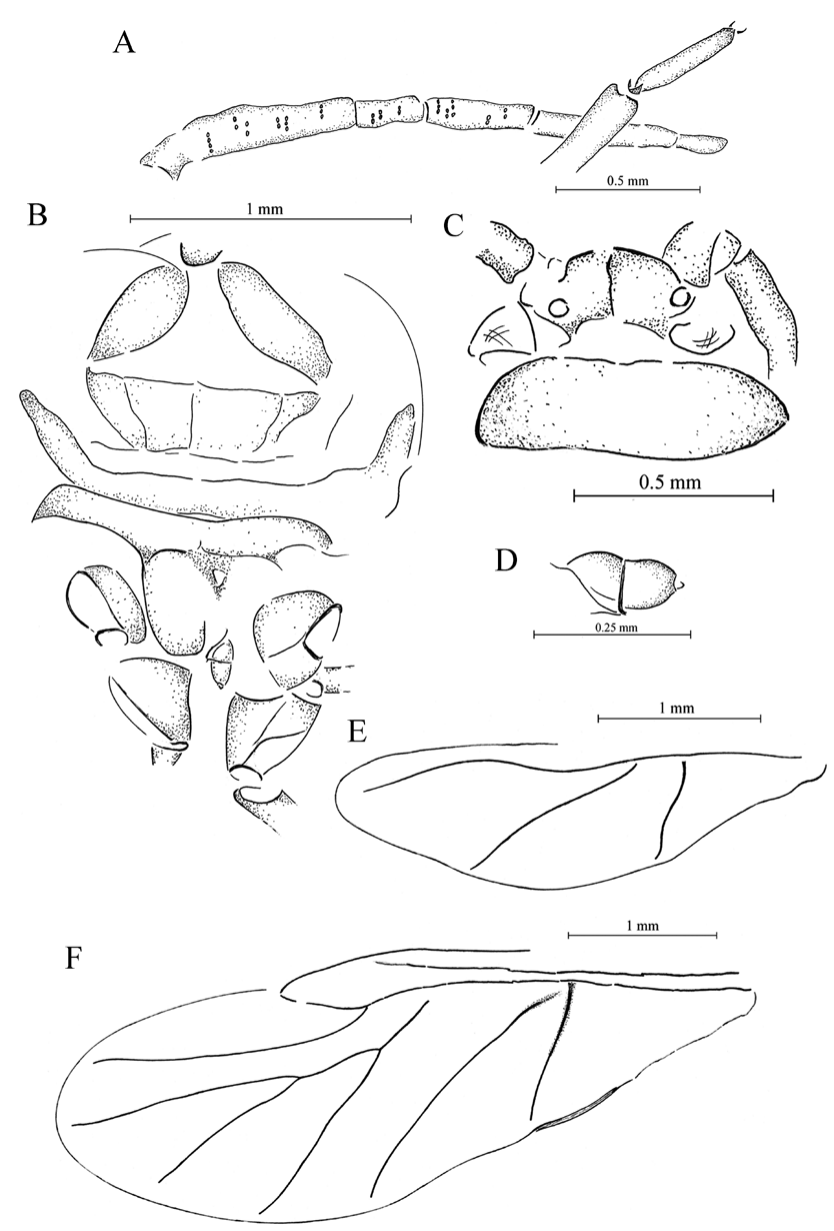

Fig. 2. Daoaphis magnalata gen. et sp. n. from the Middle Jurassic Daohugou beds, Ningcheng County, Inner Mongolia, Northeast China (NIGP 140801 holotype); drawings. A - left antenna and fore tarsus; B - body, ventral part of thorax; C - head, dorsal view; D - apical part of rostrum; E - hind wing; F - fore wing.
$\mathrm{Sc}+\mathrm{R}+\mathrm{M}$ (Ansorge, 1996). In fact, the discussed wing is quite similar to that of representatives of the Oviparosiphidae, especially the genus Vitimaphis Shaposhnikov \& Wegierek, 1989, but the absence of a body makes this assignment questionable. The most characteristic feature of this family is the presence of both an ovipositor and siphons, which are not visible in Grimmenaphis. However, the decision to exclude this genus from this family would require finding other specimens. Khotontaphis lachnoides, currently the oldest unquestionable representative of the Oviparosiphidae, has both an ovipositor and siphons clearly visible. In addition, the siphons are elongated, which is considered to be an apomorphic state of this feature (Shaposhnikov, 1980). In contrast, the newly described Daoaphis gen. n. is characterized by the plesiomorphic state, porous siphons. Elongated siphons within the Oviparosiphidae are not as rare a feature as previously thought (unpublished data), but porous ones are the most common. The occurrence of both states of features at such an early evolutionary stage of the family may suggest that within the Oviparosiphidae there were two lineages, one with porous siphons and another, in which the siphons showed a tendency for extension. It is possible that from this second group evolved representatives of the superfamily Aphidoidea, containing the vast majority of recent aphids. Several other families with both an ovipositor and siphons are known: Bajsaphididae, Sinaphididae and Canadaphididae. Only in representatives of the Bajsaphididae is the ovipositor very well developed, with all parts visible. In other families the construction of this structure is strongly reduced. Unlike in the Canadaphididae the bases of veins $\mathrm{M}$ and $\mathrm{CuA}_{1}$ are apart from each other. In the original description of the family Sinaphididae it is distinguished from the Oviparosiphidae by its disorderly arranged secondary rhinaria, veins $\mathrm{CuA}_{1}$ and $\mathrm{CuA}_{2}$ separated at bases and undeveloped basal parts

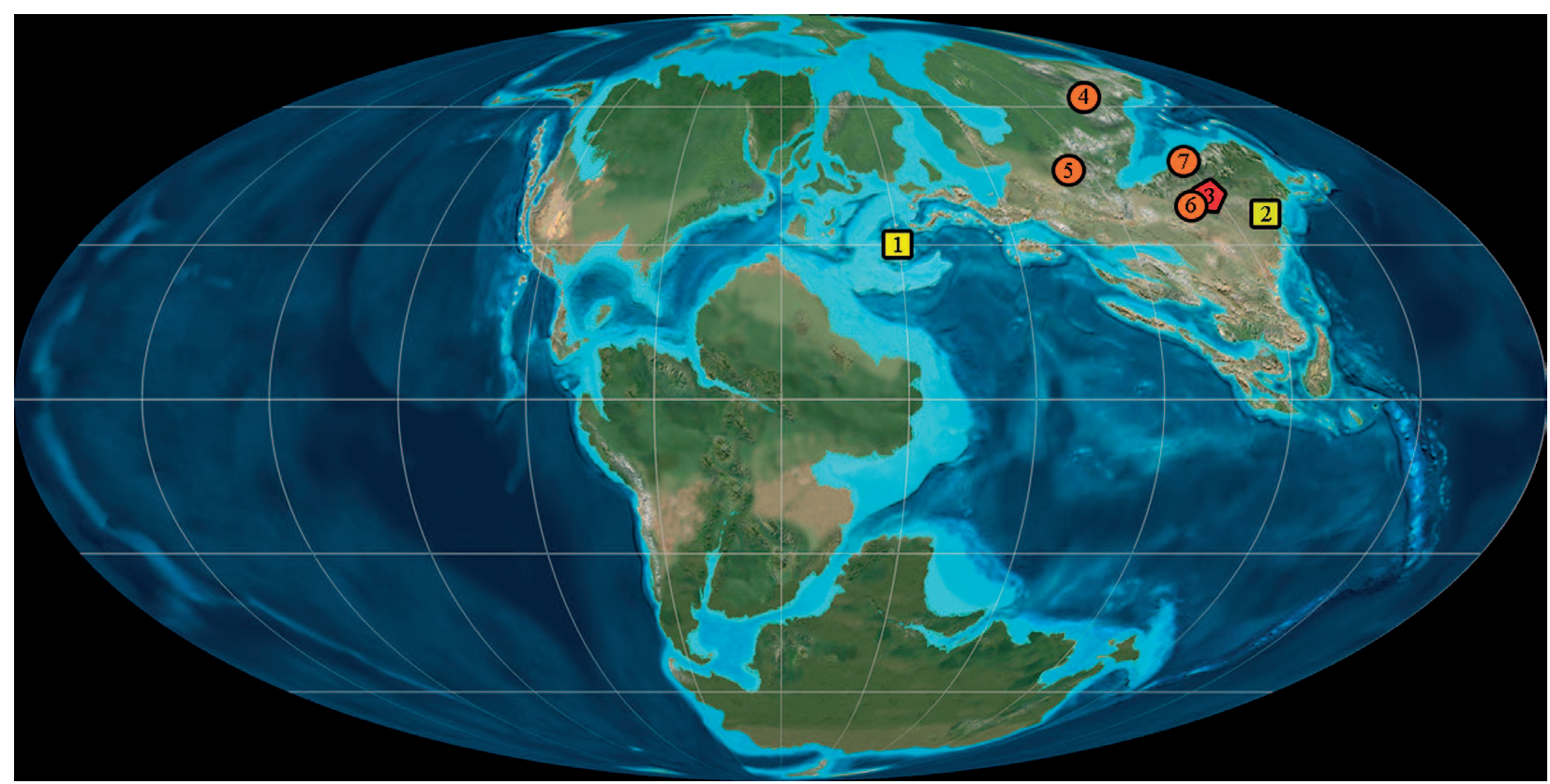

Fig. 3. Location of the deposits on a Late Jurassic map (after Blakey, 2014, changed). 1 - Grimmen; 2 - Daohugou; 3 - Khotont; 4 - Baissa; 5 - Bon-Tsagaan; 6 - Laiyang Formation; 7 - Yixan Formation. Rectangles represent the Jurassic deposits; pentagon the Jurassic/Cretaceous deposit; circles the Lower Cretaceous deposits. 
of $\mathrm{M}$ and $\mathrm{CuA}_{1}$ (Zhang et al., 1989). However, its great similarity to the representatives of the Oviparosiphidae suggests merging them into one family (as postulated by Wegierek in Ross \& Jarzembowski, 1993).

The representatives of Oviparosiphidae described from China, except Oviparosiphum latum Hong \& Wang, 1990, have antennae with fewer than 7 antennal segments, according to the original description (Zhang et al., 1989; Ren, 1995). As the newly described Daoaphis gen. n. has 7-segmented antennae it could be considered as a differentiating feature. However, the figures indicate that all representatives have the same number of antennal segments therefore this question remains unanswered until it is redescribed. The new specimen is also characterized by ellipsoidal secondary rhinaria, arranged in transverse rows. This is one of the most common arrangements in fossil aphids and typical only of extinct groups. It is considered that it could be a starting point for the more advanced forms and universal for all solutions in the construction of these structures (Shaposhnikov, 1980). The most advanced form of these sensory organs are annular rhinaria, which probably arose from merging of such small and round rhinaria in one row (Shaposhnikov, 1980).

Representatives of the family Oviparosiphidae are known from several localities (China, Germany, Mongolia, Russia, see Fig. 3) but occurred over a relatively short time span: from the Early/Middle Jurassic to the end of the Early Cretaceous. In subsequent geological epochs, the presence of this family has not been confirmed. All deposits with Oviparosiphidae have been located in the Northern Hemisphere but in different climatic regions. The oldest genera have been found in the equatorial regions and the youngest in Siberia (Baissa). This phenomenon is considered as typical for the Jurassic stage of insect evolution with the distribution of the Oviparosiphidae strong support for an 'equatorial pump' in this period. The situation was different during the Cretaceous when all the other higher-ranking taxa originated from the extratropical regions of Gondwanaland or Siberio-Canadian Province (Eskov, 2002; Kania \& Wegierek, 2008). Previously it was thought that aphids evolved at high latitudes and later some of them moved to low latitudes. Recent studies, however, show a different pattern, similar to the "equatorial pump" situation (Żyła \& Wegierek, 2014; Żyła et al., 2014). It also seems that both the spread and evolution of aphids were very strongly affected by climate changes in the Early Cretaceous when during this period, which was characterized by a generally hot climate, short colder intervals probably occurred (Föllmi, 2012).

ACKNOWLEDGEMENTS. We thank O.E. Heie and an anonymous reviewer for comments that greatly improved the manuscript. The project was supported by the National Basic Research Program of China (2012CB821903), the National Natural Science Foundation of China (91114201), the Outstanding Youth Foundation of Jiangsu Province (BK2012049).

\section{REFERENCES}

Ansorge J. 1996: Insekten aus dem Oberen Lias von Grimmen (Vorpommern, Norddeutschland). - Neue Paläontol. Abh. 2: $1-132$.

Blakey R. 2014: Colorado Plateau Geosystems, Arizona, USA. Accessed on http://cpgeosystems.com.

Chen W., Ji Q., Liu D.-Y., Zhang Y., Song B. \& Liu X.-Y. 2004: Isotope geochronology of the fossil-bearing beds in the Daohugou area, Ningcheng, Inner Mongolia. _ Geol. Bull. China 23: 1165-1169 [in Chinese with English abstr.].

EsKov K.YU. 2002: Geographical history of insects. In Rasnitsyn A.P. \& Quicke D.L.J. (eds): History of Insects. Kluwer, Dordrecht, pp. 427-437.

FöLlmi K.B. 2012: Early Cretaceous life, climate and anoxia. Cretac. Res. 35: 230-257.

HEIE O.E. 1981: Morphology and phylogeny of some Mesozoic aphids (Insecta, Hemiptera). — Fauna Entomol. Scand. (Suppl.) 15: 401-415.

Heie O.E. \& Wegrerek P. 2011: A List of Fossil Aphids (Hemiptera, Sternorrhyncha, Aphidomorpha). Monographs of the Upper Silesian Museum 6, 82 pp.

Hong Y.-C. \& WANG W.-L. 1990: Fossil insects from the Laiyang basin, Shandong province. In Regional Geological Surveying Team, Shandong Bureau of Geology and Mineral Resources (ed.): The Stratigraphy and Palaeontology of Laiyang Basin, Shandong Province. Geological Publishing House, Beijing, pp. 44-189 [in Chinese with English abstr.].

Hong Y.C., Zhang Z.J., Guo X.R. \& HeIE O.E. 2009: A new species representing the oldest aphid (Hemiptera, Aphidomorpha) from the Middle Triassic of China. - J. Paleontol. 83: 826831.

HuANG D.-Y. 2014: Trace back the origin of recent insect orders - evidence from the Middle Jurassic Daohugou Biota. - Sci. Found. China 22: 34-42.

Huang D. \& Nel A. 2008: A new Middle Jurassic aphid family (Insecta: Hemiptera: Sternorrhyncha: Sinojuraphididae fam. nov.) from Inner Mongolia, China. - Palaeontology 51: 715-719.

Huang D.-Y., Nel A., Shen Y.-B., Selden P. \& Lin Q.-B. 2006: Discussions on the age of the Daohugou fauna-evidence from invertebrates. - Prog. Nat. Sci. 16: 308-312.

Huang D.-Y., Nel A., Zompro O. \& Waller A. 2008: Mantophasmatodea now in the Jurassic. - Naturwissenschaften 95: 947-952.

Huang D.-Y., Engel M.S., CaI C.-Y., Wu H. \& Nel A. 2012: Diverse transitional giant fleas from the Mesozoic era of China. - Nature 483: 201-204.

Huang D.-Y., Nel A., Cai C.-Y., Lin Q.-B. \& Engel M.S. 2013: Amphibious flies and paedomorphism in the Jurassic period. - Nature 495: 94-97.

Kania I. \& Wegierek P. 2008: Palaeoaphididae (Hemiptera, Sternorrhyncha) from Lower Cretaceous Baissa Deposits. Morphology and Classification. Instytut Systematyki i Ewolucji Zwierząt Polskiej Akademii Nauk, Kraków, 133 pp.

Liu Y.-Q., LiU X.-Y., Li P.-X., Zhang H., Zhang L.-J., Li Y. \& XIA H.-D. 2004: Daohugou biota-bearing lithostratigraphic succession on the southeastern margin of the Ningcheng basin, Inner Mongolia, and its geochronology. - Geol. Bull. China 23: 1180-1185 [in Chinese with English abstr.].

Potт Ch., McLoughlin S., Wu S. \& FriIs E.M. 2012: Trichomes on the leaves of Anomozamites villosus sp. nov. (Bennettitales) from the Daohugou beds (Middle Jurassic), Inner Mongolia, China: Mechanical defence against herbivorous arthropods. Rev. Palaeobot. Palynol. 169: 48-60. 
RASNITSYN A.P. 2002: Special features of the study of fossil insects. In Rasnitsyn A.P. \& Quicke D.L.J. (eds): History Of Insects. Kluwer, Dordrecht, pp. 8-12.

Ren D. 1995: Systematic Paleontology part (chapter III), Homoptera, Oviparosiphidae. In Ren D., Lu L.W., Guo Z.G. \& Ji S.A. (eds): Fauna and Stratigraphy of Jurassic-Cretaceous in Beijing and the Adjacent Areas. Seismic Publishing House, Beijing, pp. 71-73.

Ross A.J. \& JARZEMBowski E.A. 1993: Arthropods (Hexapoda, Insecta). In Benton M.J. (ed.): The Fossil Record 2. Chapman \& Hall, London, 845 pp.

Shaposhnikov G.K. 1979: Late Jurassic and Early Cretaceous aphids. - Paleontol. J. 13: 449-461.

Shaposhnikov G.K. 1980: Evolution of morphological structures in aphids (Homoptera, Aphidinea) and habits of recent and Mesozoic representatives of the group. - Entomol. Obozr. 59: $39-59$.
Shcherbakov D.E. 2010: The earliest true bugs and aphids from the Middle Triassic of France (Hemiptera). - Russ. Entomol. J. 19: 179-182.

Sullivan C., Wang Y., Hone D.W.E., Wang Y.Q., Xu X. \& Zhang F.C. 2014: The vertebrates of the Jurassic Daohugou Biota of Northeastern China. - J. Vert. Paleontol. 34: 243-280.

Zhang J.F., Zhang S., Hou F. \& MA G. 1989: Late Jurassic aphids (Homoptera, Insecta) from Shandong Province, China. Geol. Shandong 5: 28-46 [in Chinese, English abstr.].

ŻyŁa D. \& Wegierex P. 2014: The oldest representatives of the aphid family Ellinaphididae and phylogenetic relationships within the family. - Cretac. Res. (in press), doi: 10.1016/j. cretres.2014.02.017.

ŻyŁa D., Blagoderov V. \& Wegierek P. 2014: Juraphididae, a new family of aphids and its significance in aphid evolution. Syst. Entomol. 39: 506-517.

Received June 29, 2014; revised and accepted September 25, 2014 Prepublished online October 20, 2014 